\title{
Garlic and $\mathrm{H}_{2} \mathrm{O}_{2}$ in overcoming dormancy on the vine "Cabernet Sauvignon"
}

\author{
Juan Saavedra del Aguila ${ }^{a}$, Ângela Pereira Dachi, Elizeu Nogueira Fernandes, Bruna Lais Hamm, Fabiane Corrêa de \\ Almeida, and Jansen Moreira Silveira
}

Federal University of Pampa (UNIPAMPA) - Bachelor of Oenology Course - Dom Pedrito Campus, Rua Vinte e Um de Abril n 80, Dom Pedrito, Rio Grande do Sul (RS), CEP 96450-000, Brazil

\begin{abstract}
The objective of this experiment was to evaluate the effect of garlic extract, $\mathrm{H}_{2} \mathrm{O}_{2}$ and hydrogen cyanamide on dormancy break, budding and maturation of "Cabernet Sauvignon" in the Campaign Region - Brazil. In late winter 2014 and after drought pruning were performed spraying in the bud: T1 - distilled water (control); 2 - 3.0\% of hydrogen cyanamide; $\mathrm{T} 3-18.0 \% \mathrm{H}_{2} \mathrm{O}_{2}$; and $\mathrm{T} 4-3.0 \%$ garlic extract. It was evaluated in the field: the number of sprouted buds per plant, number of bunches per plant and weight of bunches per plant; and laboratory: on ripening, performed weekly from the color change of 360 berries per treatment for analyzes solids soluble - SS (Brix) $\mathrm{pH}$ and titratable acidity - TA (\% tartaric acid). It was observed that the vines of treatment T4 (3.0\% garlic extract), showed higher percentage of buds sprouting (63 shoots plant $\left.{ }^{-1}\right)$. Already at the number of clusters and weight per plant, there were no statistical differences between all treatments. The results obtained in the laboratory to SS, $\mathrm{pH}$ and TA did not differ statistically for the four tested treatments.
\end{abstract}

\section{Introduction}

Once dormancy is induced, it is maintained by unknown mechanisms [1]. The period of dormancy is integral to the survival of the vine in areas where winter temperatures fall bellow $0^{\circ} \mathrm{C}$, although dormancy is also an important part of the vine cycle in warmer areas who Brazil, too [2].

The vine Vitis vinifera "Cabernet Sauvignon" comes from Bordeaux, south-western France (natural hybrid between "Cabernet Franc" and "Sauvignon Blanc" [3]. It is one of the more grapes planted in the world, the production of quality wine in several countries. In Brazil produces fine red wine best conditions for aging. He had a great expansion from 1970 begins to decline recently. However, it remains the largest area of ink Vinifera in Brazil [4]. The "Cabernet Sauvignon" latency issues can occur when the winter is mild or when the vineyard is located in the regions with the number of chill hours below $10^{\circ} \mathrm{C}[5]$. The mild fruit characterized by dropping their leaves at the end of the cycle going dormant in winter, reducing their metabolic activities, which need to be exposed to a period of low temperatures to start a new cycle in the spring [6].

Latency deciduous plants such as internal factors involve balancing promoters and growth inhibitors, or external, such as temperature, photoperiod and solar radiation, among others. Of external factors, which most stands out is the temperature, and when the plants are grown in areas with shortages of winter cold, symptoms of mismatches are the delay and the longer period of bloom and the lower opening of flowering and vegetative buds, resulting in lower production, with uneven and low quality fruits [7].

${ }^{a}$ Corresponding author: juanaguila@unipampa.edu.br
In regions where no dormancy is overcome by the cold of winter, or the varieties used have a chilling hour's requirement, there is the need to use chemicals to break dormancy [8]. Several products are effective in overcoming latency, such as mineral oil, hydrogen cyanamide, calcium cyanamide and Thidiazuron. With mineral oil and recommended as one of the most effective ways to induce fruit leaf buds hydrogen cyanamide expires in Brazil as the vine [9].

The effect of hydrogen cyanamide, however, varies depending on various factors such as the concentration, time and mode of application, weather conditions and growing [10]. Overall, the increase in the percentage of sprouted buds leads to greater productivity and better training for the branches to be pruned the following year [11]. The use of this growth regulator also produces an advance of the date of the harvest, about 15-20 days, due to the higher concentration of sugars in the berries, due to the earlier onset of leaf development [12].

Despite its current use in various parts of the world, little is known about the mode of action of this substance in break dormancy. Furthermore, the substance has a high toxicity [13].

The objective of this experiment was to evaluate the effect of hydrogen cyanamide, hydrogen peroxide and garlic extract to overcome latency, budding and ripening cultivar "Cabernet Sauvignon" in "Campanha Gaucha" - Brazil.

\section{Materials and methods}

The research was conducted in the vineyard of "Cabernet Sauvignon" clone R5 and rootstock "SO4", planted in 2000 , based on a trellis and driven in cord Royat, on private property in the municipality of Dom Pedrito - RS - Brazil. 
The experimental design was a randomized block design with four replicates each with five floors for a total of twenty plants per treatment. In late winter 2014, after spraying the dry pruning gems were performed: $\mathrm{T} 1$ - water distilled (control); $\mathrm{T} 2-3.0 \%$ of hydrogen cyanamide; $\mathrm{T} 3-18.0 \%$ hydrogen peroxide $\left(\mathrm{H}_{2} \mathrm{O}_{2}\right)$; and $\mathrm{T} 4-3.0 \%$ extract of garlic.

It was evaluated in the field: the number of sprouted buds per plant, number of bunches per plant and weight of bunches per plant.

On ripening, performed weekly from the color change of 360 berries per treatment for analyzes in laboratory: the soluble solids concentration - SSC was determined by direct reading of grape juice in a digital refractometer (Atago PR-101, Atago Co. Ltd., Tokyo, Japan), with the results expressed in ${ }^{\circ}$ Brix. Titratable acidity (TA) was determined from $10 \mathrm{~g}$ of grape juice diluted with $90 \mathrm{~mL}$ of water, titrated with $0.1 \mathrm{~N} \mathrm{NaOH}$ to $\mathrm{pH} 8.1$ and expressed in percentage of tartaric acid, once this acid represents approximately $80 \%$ of the total organic acids present in grape; $\mathrm{pH}$ was determined with potentiometer.

The data were subjected to analysis of variance and the least significant differences were calculated using SAS software for the randomized block design with four replicates each with five floors for a total of twenty plants per treatment. Differences between any two treatments greater than the sum of two standard deviations were always significant $(P>0.05)$.

\section{Results and discussion}

It was observed that the vines of treatment T4 (3.0\% garlic extract), showed higher percentage of buds sprouting $\left(63\right.$ shoots plant $\left.^{-1}\right)$ (Fig. 1).

The use of endodormancy-releasing chemicals is limited to instances where insufficient natural chilling occurs for adequate bud break and crop production [1], who is the case of the region where executed this project.

Already at the number of clusters and weight per plant, there were no statistical differences between all treatments (Figs. 2 and 3).

The results obtained in the laboratory to $\mathrm{SS}, \mathrm{pH}$ and TA did not differ statistically for the four tested treatments.

The "Cabernet Sauvignon", synonymous with serious red wine capable of ageing into subtle splendour. For this reason "Cabernet Sauvignon" is also the best-travelled red

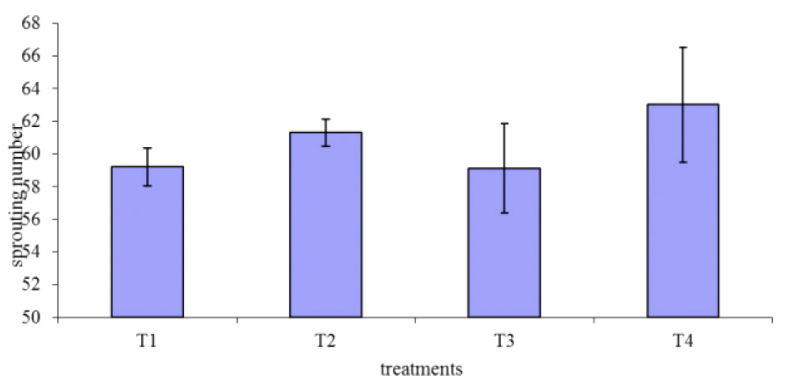

Figure 1. Sprouting percentage grape "Cabernet Sauvignon". T1 - distilled water (control); T2 - 3.0\% of hydrogen cyanamide; $\mathrm{T} 3-18.0 \%$ and hydrogen peroxide; T4 $-3.0 \%$ extract of garlic. Vertical bars represent \pm S.D. $(n=20)$.

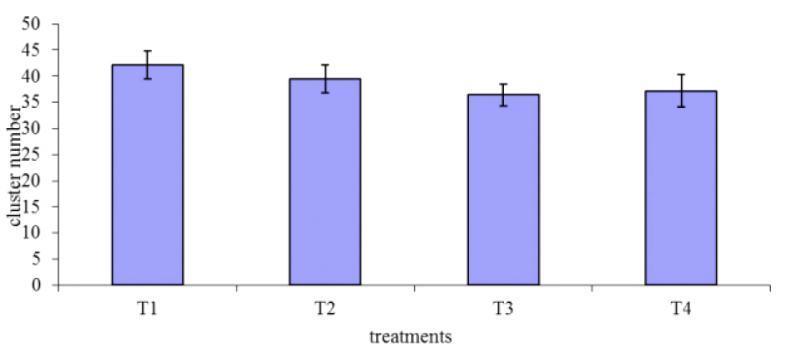

Figure 2. Number of clusters per plant grape "Cabernet Sauvignon". $\mathrm{T} 1$ - distilled water (control); T2 $-3.0 \%$ of hydrogen cyanamide; $\mathrm{T} 3-18.0 \%$ and hydrogen peroxide; T4 $-3.0 \%$ extract of garlic. Vertical bars represent \pm S.D. $(n=20)$.

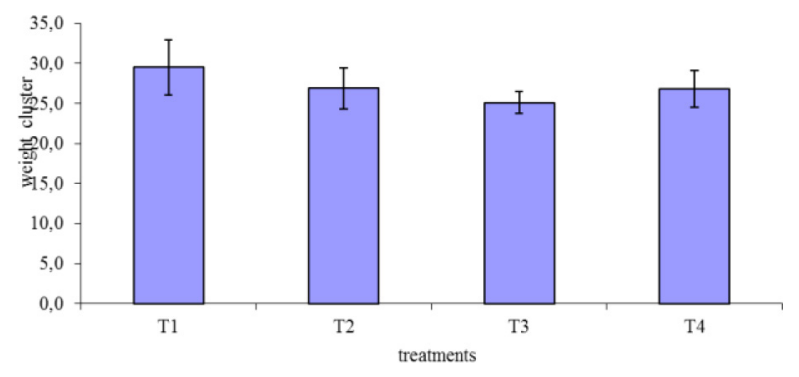

Figure 3. Weight of clusters per plant grape "Cabernet Sauvignon". $\mathrm{T} 1$ - distilled water (control); T2 $-3.0 \%$ of hydrogen cyanamide; $\mathrm{T} 3-18.0 \%$ and hydrogen peroxide; $\mathrm{T} 4-3.0 \%$ extract of garlic. Vertical bars represent \pm S.D. $(n=20)$.

wine variety, but since it is a relatively late ripener it is viable only in warmish climates [14].

\section{Conclusions}

The plants that received a dose of $3.0 \%$ garlic extract presented the highest percentage of sprouted buds. For analysis of maturation, the presence of hydrogen cyanamide, hydrogen peroxide, such as garlic extract did not influence the quality of the grapes "Cabernet Sauvignon".

\section{References}

[1] E.F. Durner. Principles of Horticultural Physiology. Cabi, 405p (2013)

[2] G.L. Creasy, L.L. Creasy. Grapes. Cabi, 295p (2009)

[3] E. Giovannini. Manual de Viticultura, 93p. (2014)

[4] E. Giovannini, V. Manfroi. Viticultura e Enologia Elaboração de grandes vinhos nos terroirs brasileiros. IFRS, 23p (2009)

[5] L. Spadari, E. Giovannini. Quebra de dormência em "Cabernet Sauvignon" (vitis vinífera L.) com cianamida hidrogenada. $R$. B. V. E, n1, 21p (2009)

[6] J. L. Petri, et al. Dormência e indução da brotação de fruteiras de clima temperado. Epagri, 110p (1996)

[7] G. A. B. Marodin, A. H. D. Francisconi, E. S. P. Gallois. Efeito de produtos químicos na quebra de dormência e produção de pereira (Pyrus communis, L.) cv Packham's Triunph. R. B. F., 14, n.1, p.155 - 160, (1992). 
[8] E. Giovannini, V. Manfroi. Viticultura e Enologia Elaboração de grandes vinhos nos terroirs brasileiros. IFRS, 96p (2009)

[9] J. L. Petri, L. A. Palladini, A. C. Pola. Dormência e indução da brotação da macieira. Epagri. Manual da cultura da macieira, 261-298p. (2002)

[10] A. Miele. Efeito da Cianamida Hidrogenada na quebra de dormência das gemas, produtividade do vinhedo e composição química do mosto da uva Cabernet Sauvignon. (1991)
[11] E. Giovannini, V. Manfroi. Viticultura e Enologia Elaboração de grandes vinhos nos terroirs brasileiros. IFRS, 96p (2009)

[12] L. F. C. Hidalgo, J. H. Torgores. Tratado de Viticultura, 1033p. (2011)

[13] J. C. Guimarães. Liberação da dormência e dinâmica de carboidratos em gemas de videiras niagara rosada (Vitis labrusca L.) em Região tropical. (2013)

[14] M. Beazley. The concise world atlas of wine, Octopus, 352p. (2009) 